Britain, the United States, other European countries, and Germany (for example, Journal of Physiology, American Journal of Physiology, Archives internationales de Physiologie, Pflügers Archiv) has been made for the years 1938-39, 1950 and 1951, and shows that in these last two years the cost of German journals exceeded the combined sum expended on the others, although the increase on account of devaluation of sterling amounted to 45 per cent for American, and 26 per cent only for German periodicals. Compared with 1933 , the totalled prices of the sets of journals in the four categories, taking the average of 1950 and 1951 in each case, may be presented in simple ratio as follows :

$\begin{array}{lcccc} & & & \text { Other } & \\ & \text { British } & \text { American } & \text { countries } & \text { Germany } \\ 1933 & 1 \cdot 0 & 1 \cdot 06 & 0.875 & 3 \cdot 8 \\ 1950-51 \text { (averaged) } & 1 \cdot 0 & 1 \cdot 69 & 0 \cdot 96 & \mathbf{4} \cdot 15\end{array}$

showing that the case for a reduction in price of German periodicals holds again.

A further table has been compiled showing that of these German periodicals from different publishing houses, those emanating from the Springer Verlag are three $(3 \cdot 2)$ times the cost of the others, and although the 1951 figures for Springer publications show a reduction on 1950 prices, the fall would appear to be due not to a reduction in price but to one in output.

We are told by experts that the post-war value of German scientific and medical periodicals is scarcely yet up to pre-war standard, but is still of high enough quality to justify their purchase by those who can afford them. It is obvious that German scientists will do their utmost to achieve the highest standard, and we are assured that they are prepared to co-operate in this effort to reduce the excessive price of their journals. We are sure it will be agreed that their output is as essential to research as that of other countries, and curtailment of its circulation owing to prohibitive costs is to be deplored. American librarians are equally anxious to find a solution to this problem, as has been evidenced in our correspondence with them.

It is impossible to print here the full text of this investigation, done in 1950 and revised for 1951 ; but a copy will be sent on request to those interested.

REFERENCES

"Prices of Periodical Scientiflc Publications", Nature, 121, 538 (1928). "The Cost of German Biological Periodicals", Library Association Record, N.S. 6, 252 (1928).

"Cost of German Scientiflc Periodicals", Nature, 132, 34 (1933).

"Cost of German Scientifle Periodicals" (Notice by Börsenverein of reduction by 20 per cent), Nature, 132, 540 (1933).

(Notice of further) "Reduction in Price of German Books and Periodicals" (by 25 per cont), Nature, 136, 510 (1935).

\section{FUNDAMENTAL PARTICLES}

CCIENCE PROGRESS of April (40, No. 158, 193 ; $S$ 1952) contains an interesting and informative article by Prof. H. S. W. Massey entitled "Fundamental Particles", the term which is applied usually to such entities as electrons, protons, etc. Prof. Massey points out, however, that the quantum theoretical description of the physical world is a dualistic one in which mechanical phenomena are viewed from both a particle and a wave aspect and that classical physics is the limiting case when $h$, Planck's constant, tends to zero. It is better, therefore, when describing the fundamental nature of matter and radiation to begin with the purely wave description and then, by imposing quantization, to lead to the particle aspect.

It is Prof. Massey's contention that the general features and consequences of the application of quantum theory to wave fields can be made clear without the use of elaborate mathematics and can be appreciated without a detailed knowledge of physics, and after reading his admirable article the reader will doubtless agree with Prof. Massey. The quantized electromagnetic field and its associated particles, the photons, are dealt with first, then the electron field and finally the interaction between the two fields. It is shown that at no stage is it necessary to postulate action at a distance, but that the necessary interaction betw'een particles can be transmitted through the electromagnetic field vacuum photons.

Turning next to the subject of the classification of the fundamental wave particles, Prof. Massey shows that the particles can be loosely separated into three categories, which he aptly terms "building stones" (electron, proton and neutron), "cements" (photon and pi-meson) and "bric-a-brac" (neutrino, mu-, V-, tau- and kappa-mesons). The first two categories, as their names imply, are involved in the structure of matter, but the third, apparently, does not fulfil any important role in that respect. The properties of the various particles and the relations between them are briefly and clearly described, and it is evident that their number (now some twenty-four) is far too large for them all to be fundamental. Nevertheless, as Prof. Massey states, the discovery of new particles is still a prominent feature of modern physics, and thus, until some new fundamental advance or simplification is made on the theoretical side, not only to provide a basis for the "bric-a-brac" but possibly also to account for the more complete range of particles yet to be explored, the fundamental scheme of Nature must remain obscure.

S. WeINTROUB

\section{DATING THE LIBYAN DESERT SILICA-GLASS}

\section{By DR. KENNETH P. OAKLEY}

Department of Geology, British Museum (Natural History)

DIECEs of natural silica-glass up to $16 \mathrm{lb}$. in weight occur scattered sparsely in an oval area measuring $130 \mathrm{~km}$. north to south and $53 \mathrm{~km}$. from east to west, in the Sand Sea of the Libyan Desert. This remarkable material, which is almost pure $\left(97\right.$ per cent $\mathrm{SiO}_{2}$ ), relatively light (sp. gr. $2 \cdot 21$ ), clear and yellowish-green in colour, has the qualities of a gemstone. It was discovered by the Egyptian Survey Expedition under Mr. P. A. Clayton in 1932, and was thoroughly investigated by Dr. L. J. Spencer, who joined a special expedition of the Survey for this purpose in 1934.

The pieces are found in sand-free corridors between north-south dune ridges, about $100 \mathrm{~m}$. high and 2-5 km. apart. These corridors or 'streets' have a rubbly surface, rather like that of a 'speedway' track, formed by angular gravel and red loamy weathering debris overlying Nubian Sandstone. The pieces of glass lie on this surface or partly embedded in it. Only a few small fragments were found below the surface, and none deeper than about 1 metre. All the pieces on the surface have been pitted or smoothed by sand-blast. The distribution of the glass is patchy 